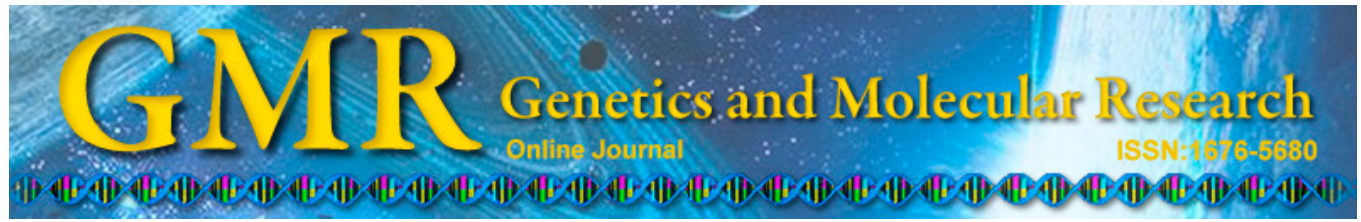

\title{
Effect of polymorphisms of vascular endothelial growth factor on prognosis in osteosarcoma patients
}

\author{
X.D. Li ${ }^{1}$, D.D. Yu ${ }^{2}$, J.R. Lu ${ }^{1}$, C. Wu ${ }^{1}$ and W.X. Jin ${ }^{1}$ \\ ${ }^{1}$ Department of Joint Surgery, Zhejiang Provincial Corps Hospital, \\ Chinese People's Armed Police Forces, JiaXing, China \\ ${ }^{2}$ Department of Ophthalmology, Zhejiang Provincial Corps Hospital, \\ Chinese People's Armed Police Forces, JiaXing, China \\ Corresponding author: X.D. Li \\ E-mail: lixiaodong6676@163.com
}

Genet. Mol. Res. 14 (2): 4354-4360 (2015)

Received May 21, 2014

Accepted August 27, 2014

Published April 30, 2015

DOI http://dx.doi.org/10.4238/2015.April.30.8

\begin{abstract}
We investigated the association between vascular endothelial growth factor (VEGF) gene $+1612 \mathrm{G} / \mathrm{A},-634 \mathrm{C} / \mathrm{G}$, and $+936 \mathrm{G} / \mathrm{C}$ and the clinical outcome of osteosarcoma. Genomic DNA was isolated from blood samples, and 3 VEGF gene polymorphisms $(+1612 \mathrm{G} / \mathrm{A},-634 \mathrm{C} / \mathrm{G}$, and $+936 \mathrm{G} / \mathrm{C})$ were analyzed using polymerase chain reaction-restriction fragment length polymorphism. Of the 194 patients, 82 patients $(42.27 \%)$ showed a good response to chemotherapy, while $73(37.63 \%)$ died during the follow-up period. When comparing good and poor responders, we observed no significant association between the VEGF $+1612 \mathrm{G} / \mathrm{A}$, $-634 \mathrm{G} / \mathrm{C}$, and $+936 \mathrm{~T} / \mathrm{C}$ polymorphisms and clinical outcome of osteosarcoma patients. According to Cox regression analysis, the $\mathrm{VEGF}+1612 \mathrm{~A} / \mathrm{G},-634 \mathrm{G} / \mathrm{C}$, and $+936 \mathrm{~T} / \mathrm{C}$ polymorphisms did not statistically significantly increase the risk of overall survival of patients with osteosarcoma. This study showed that VEGF $+1612 \mathrm{~A} / \mathrm{G},-634 \mathrm{G} / \mathrm{C}$, and $+936 \mathrm{~T} / \mathrm{C}$ polymorphisms were not
\end{abstract}


related to the response to chemotherapy and clinical outcome of osteosarcoma patients.

Key words: Chemotherapy; Clinical outcome; Osteosarcoma; Vascular endothelial growth factors

\section{INTRODUCTION}

Human osteosarcoma is one of the most common primary malignant bone tumors, often originating in the metaphyses of long bones and occurring in children and adolescents (Ries et al., 1999; Savage et al., 2007; Duong and Richardson, 2013). It is estimated that there are 4-5 cases per million worldwide, and is a leading cause of cancer-related deaths in children and young adults (Ries et al., 1999). Because of the high incidence of systemic spread, the prognosis of patients with osteosarcoma is unsatisfactory (Longhi et al., 2006). Through combinatorial chemotherapy, the 5-year survival rate of patients with osteosarcoma has been greatly improved to $60-70 \%$ in recent years (Longhi et al., 2001). However, $40 \%$ of osteosarcoma patients still show poor response to chemotherapy, with a high risk of local recurrence and distant metastasis even after receiving curative resection of the primary tumor and intensive chemotherapy (Collins et al., 2013). Moreover, the molecular events initiating and propagating osteosarcomagenesis remain unknown. Therefore, the identification of genetic factors that may influence chemotherapy toxicity and clinical outcome of osteosarcoma can be helpful for improving osteosarcoma treatment.

The vascular endothelial growth factors (VEGF) gene is one of the most potent endothelial cell mitogenes and consists of 8 exons located on chromosome 6p21.3; the gene exhibits alternative splicing to form a family of proteins (Vincenti et al., 1996). VEGF is a potent regulator of angiogenesis and thus plays a role in the development and prognosis of solid tumors (Kapahi et al., 2014; James et al., 2014). Several common single-nucleotide polymorphisms (SNPs) in the VEGF gene have been reported to have a role in gene expression. Three potentially functional SNPs of the VEGF gene, VEGF $+1612 \mathrm{G} / \mathrm{A},-634 \mathrm{C} / \mathrm{G}$, and $+936 \mathrm{~T} / \mathrm{C}$, influence plasma VEGF levels. VEGF gene polymorphisms are associated with various cancers, such as lung, colorectal, breast, oral, ovarian, gastric, and bladder cancers (Kim et al., 2013; Leng et al., 2013; Fu et al., 2013; Oh et al., 2013; Jaiswal et al., 2013; Kushlinskii et al., 2014).

Although several studies reported an association between VEGF polymorphisms and cancer risk, few studies have examined the association between the 3 gene polymorphisms and clinical outcome of patients with osteosarcoma. Only one study investigated the association between VEGF polymorphisms and risk of osteosarcoma (Wang et al., 2014). The aim of this study was to investigate the association between VEGF gene $+1612 \mathrm{G} / \mathrm{A},-634 \mathrm{C} / \mathrm{G}$, and $+936 \mathrm{~T} / \mathrm{C}$ and the clinical outcome of osteosarcoma.

\section{MATERIAL AND METHODS}

All patients in our study were histologically confirmed to have osteosarcoma between January 2008 and December 2010 at Zhejiang Provincial Corps Hospital. These patients were newly diagnosed within 1 month. Written informed consent was obtained from each patient before inclusion in the study. The protocol of this study was approved by the ethics committee board of the Zhejiang Provincial Corps Hospital. 
All patients in this study received chemotherapy before surgery, including doxorubicin, methotrexate, and cisplatin. After surgery, all patients received adjuvant chemotherapy, including methotrexate, cisplatin and vincristine, and cyclophosfamide. Response to chemotherapy was divided into 2 groups according to criteria from the European Organization for Research and Treatment of Cancer, including good responders and poor responders. Overall survival (OS) was calculated to evaluate the association between VEGF polymorphisms and osteosarcoma prognosis. OS was assessed from the date of entrance into the study until the date of death or the last follow-up. All patients selected were followed up until the December 31, 2012.

\section{DNA extraction and polymerase chain reaction (PCR) amplification}

All patients were asked to provide $5 \mathrm{~mL}$ venous blood, and genomic DNA was isolated using a Qiagen Blood Kit (Qiagen, Hilden, Germany) according to manufacturer instructions. Polymorphisms of VEGF $+1612 \mathrm{G} / \mathrm{A},-634 \mathrm{C} / \mathrm{G}$, and $+936 \mathrm{~T} / \mathrm{C}$ were assessed by PCR-restriction fragment length of polymorphism. Primers of VEGF $+1612 \mathrm{G} / \mathrm{A},-634 \mathrm{C} / \mathrm{G}$, and $+936 \mathrm{~T} / \mathrm{C}$ were designed using the Sequenom Assay Design 3.1 software (San Diego, CA, USA), as shown in Table 1 . The PCR reaction was performed in $50 \mu \mathrm{L}$ reaction solution containing $25 \mathrm{mM} \mathrm{MgCl}_{2}, 2 \mathrm{mM} 4 \mathrm{X}$ dNTPs, $20 \mu \mathrm{M}$ primer, and $5 \mathrm{U} / \mu \mathrm{L}$ Taq DNA polymerase. The PCR reaction was performed under the following conditions: beginning at $94^{\circ} \mathrm{C}$ for $5 \mathrm{~min}$, followed by 35 cycles of denaturing at $94^{\circ} \mathrm{C}$ for $45 \mathrm{~s}$, annealing at $62^{\circ} \mathrm{C}$ for $60 \mathrm{~s}$, and extension at $72^{\circ} \mathrm{C}$ for $60 \mathrm{~s}$; final extension was performed at $72^{\circ} \mathrm{C}$ for $10 \mathrm{~min}$. The PCR products were visualized by $1.0 \%$ agarose gel electrophoresis with staining using ethidium bromide staining and ultraviolet light. For quality control, a group randomly chosen of $10 \%$ of the cases and control subjects were selected, and the results of repeated samples showed $100 \%$ concordance.

Table 1. Primers of VEGF genetic polymorphisms for PCR-RFLP analysis.
\begin{tabular}{llcl}
\hline SNPs & Primer sequences & Restriction enzymen & PCR products (bp) \\
\hline$+1612 \mathrm{G} / \mathrm{A}$ & 5'-CACATGCTGCACGCGCATCTC A-3' & MnlI & AA: 206 \\
& 5'-ACCCCAGGAAGG GGAGCAGGA-3' & & AG: $206,180,26$ \\
-634C/G & 5'-GTAGCAAGAGCTCCAGAGAGAAGT-3' & BsmFI & CC: 197 \\
& 5'-TGGACGAAAAGTTCAGTGCGACG-3' 26 \\
$+936 \mathrm{~T} / \mathrm{C}$ & 5'-CTC GGT GATTTAGCAGCAAG-3' & & CG: $197,157,40$ \\
& 5'-CTCGGTGATTAGCAGCAAG-3' & NlaIII & GG: 157,40 \\
& & & TT: 122,86 \\
& & & TC: $208,122,86$ \\
\hline
\end{tabular}

\section{Statistical analysis}

Continuous variables were expressed as means \pm standard deviation, and categorical variables were expressed as $\mathrm{N}(\%)$ of study participants. The odds ratios (OR) and corresponding $95 \%$ confidence intervals (CIs) were calculated by unconditional logistic regression analysis and utilized to assess the potential association between genotypes frequencies and response to chemotherapy of osteosarcoma patients. Survival distributions were assessed using the KaplanMeier method and a log-rank test. HRs and their CIs were used to analyze the association between VEGF $+1612 \mathrm{G} / \mathrm{A},-634 \mathrm{C} / \mathrm{G}$, and $+936 \mathrm{~T} / \mathrm{C}$ and survival time using a multivariate Cox proportional hazards model. All tests were 2 -sided and $\mathrm{P}<0.05$ was considered to be statistically significant. 


\section{RESULTS}

The demographic and clinical distributions of cases included are shown in Table 2. A total of 194 patients were included in our study. The mean age at diagnosis of all patients was $17.8 \pm 12.5$ years. Of the 194 osteosarcoma patients, $143(73.71 \%)$ were less than 20 years old, $130(67.01 \%)$ were male, and $100(51.55 \%)$ showed tumor location at the femur, $66(34.02 \%)$, in the tibia/fibula, $138(71.13 \%)$ did not show metastasis, $114(58.76 \%)$ received limb salvage, $112(57.73 \%)$ showed poor response to chemotherapy, and $73(37.63 \%)$ died during the follow-up period.

\begin{tabular}{|c|c|c|}
\hline Indexes & Patients, N & $\%$ \\
\hline Age at diagnosis, y & $17.8 \pm 12.5$ & \\
\hline$\leq 20$ & 143 & 73.71 \\
\hline$>20$ & 51 & 26.29 \\
\hline \multicolumn{3}{|l|}{ Gender } \\
\hline Male & 130 & 67.01 \\
\hline Female & 64 & 32.99 \\
\hline \multicolumn{3}{|l|}{ Tumor location } \\
\hline Femur & 100 & 51.55 \\
\hline Tibia/fibula & 66 & 34.02 \\
\hline Arm & 15 & 7.73 \\
\hline Central & 13 & 6.70 \\
\hline \multicolumn{3}{|l|}{ Metastasis } \\
\hline No & 138 & 71.13 \\
\hline Yes & 56 & 28.87 \\
\hline \multicolumn{3}{|l|}{ Therapy } \\
\hline Amputation & 80 & 41.24 \\
\hline Limb salvage & 114 & 58.76 \\
\hline \multicolumn{3}{|c|}{ Chemotherapy response } \\
\hline Poor & 112 & 57.73 \\
\hline Good & 82 & 42.27 \\
\hline \multicolumn{3}{|l|}{ Death } \\
\hline No & 121 & 62.37 \\
\hline Yes & 73 & 37.63 \\
\hline
\end{tabular}

Of the 194 patients, 82 patients $(42.27 \%)$ showed a good response to chemotherapy (Table 3 ). When comparing good and poor responders, we observed no significant association between VEGF $+1612 \mathrm{G} / \mathrm{A},-634 \mathrm{G} / \mathrm{C}$, and $+936 \mathrm{~T} / \mathrm{C}$ polymorphisms and clinical outcome of osteosarcoma patients.

\begin{tabular}{|c|c|c|c|c|c|c|c|c|c|}
\hline \multirow[t]{2}{*}{ Genotype } & & \multirow[t]{2}{*}{ Patients N $=194$} & \multirow[t]{2}{*}{$\%$} & \multicolumn{4}{|c|}{ Tumor response } & \multirow[t]{2}{*}{ OR $(95 \% \mathrm{CI})$} & \multirow[t]{2}{*}{$P$ value } \\
\hline & & & & Good & $\%$ & Poor & $\%$ & & \\
\hline \multirow{3}{*}{$+1612 \mathrm{G} / \mathrm{A}$} & GG & 71 & 36.60 & 31 & 38.2 & 40 & 35.71 & 1.0 (Ref.) & - \\
\hline & GA & 90 & 46.39 & 36 & 44.3 & 54 & 48.21 & $0.86(0.44-1.70)$ & 0.64 \\
\hline & AA & 33 & 17.01 & 14 & 17.5 & 19 & 16.96 & $0.95(0.38-2.37)$ & 0.91 \\
\hline \multirow[t]{3}{*}{$-634 \mathrm{G} / \mathrm{C}$} & $\mathrm{CC}$ & 74 & 38.14 & 34 & 41.3 & 40 & 35.71 & 1.0 (Ref.) & - \\
\hline & $\mathrm{CT}$ & 100 & 51.55 & 41 & 50.2 & 59 & 52.68 & $0.82(0.43-1.57)$ & 0.51 \\
\hline & $\mathrm{TT}$ & 20 & 10.31 & 7 & 8.5 & 13 & 11.61 & $0.63(0.19-1.95)$ & 0.38 \\
\hline \multirow[t]{3}{*}{$+936 \mathrm{~T} / \mathrm{C}$} & $\mathrm{TT}$ & 96 & 49.48 & 43 & 52.6 & 53 & 47.32 & 1.0 (Ref.) & - \\
\hline & $\mathrm{TC}$ & 76 & 39.18 & 32 & 38.6 & 44 & 39.29 & $0.90(0.47-1.72)$ & 0.72 \\
\hline & $\mathrm{CC}$ & 22 & 11.34 & 7 & 8.8 & 15 & 13.39 & $0.58(0.18-1.67)$ & 0.27 \\
\hline
\end{tabular}


Table 4 shows the potential association between VEGF genetic polymorphisms and overall survival of patients with osteosarcoma. After adjusting for potential confounding factors, we did not find that VEGF $+1612 \mathrm{G} / \mathrm{A},-634 \mathrm{G} / \mathrm{C}$, and $+936 \mathrm{~T} / \mathrm{C}$ polymorphisms statistically significant increased the risk of overall survival of patients with osteosarcoma.

\begin{tabular}{|c|c|c|c|c|c|c|c|c|c|}
\hline Genotype & & Patients N $=194$ & $\%$ & $\begin{array}{l}\text { Death } \\
\text { Event }\end{array}$ & $\%$ & $\begin{array}{l}\text { Alive } \\
\text { Event }\end{array}$ & $\%$ & $\mathrm{HR}(95 \% \mathrm{CI})^{1}$ & $\mathrm{P}$ value \\
\hline \multirow[t]{3}{*}{$+1612 \mathrm{G} / \mathrm{A}$} & $\mathrm{GG}$ & 71 & 36.6 & 24 & 32.88 & 47 & 38.84 & 1.0 (Ref.) & - \\
\hline & GA & 90 & 46.39 & 35 & 47.95 & 55 & 45.45 & $1.25(0.62-2.52)$ & 0.51 \\
\hline & AA & 33 & 17.01 & 14 & 19.18 & 19 & 15.70 & $1.44(0.56-3.65)$ & 0.4 \\
\hline \multirow[t]{3}{*}{$-634 \mathrm{G} / \mathrm{C}$} & $\mathrm{CC}$ & 74 & 38.14 & 25 & 34.25 & 49 & 40.50 & 1.0 (Ref.) & - \\
\hline & $\mathrm{CT}$ & 100 & 51.55 & 38 & 52.05 & 62 & 51.24 & $1.20(0.61-2.37)$ & 0.57 \\
\hline & $\mathrm{TT}$ & 20 & 10.31 & 10 & 13.70 & 10 & 8.26 & $1.96(0.63-5.99)$ & 0.18 \\
\hline \multirow{3}{*}{$+936 \mathrm{~T} / \mathrm{C}$} & TT & 96 & 49.48 & 33 & 45.21 & 63 & 52.07 & 1.0 (Ref.) & - \\
\hline & $\mathrm{TC}$ & 76 & 39.18 & 30 & 41.10 & 46 & 38.02 & $1.25(0.64-2.43)$ & 0.49 \\
\hline & $\mathrm{CC}$ & 22 & 11.34 & 10 & 13.70 & 12 & 9.92 & $1.59(0.55-4.49)$ & 0.33 \\
\hline
\end{tabular}

${ }^{1}$ Adjusted for gender, age, tumor location, metastasis, and therapy methods.

\section{DISCUSSION}

VEGF is a growth factor that regulates angiogenesis, and is considered to be the most potent stimulatory cytokine modifying tumor angiogenesis and regulating tumor metastasis, survival, and tumor spread (Salven et al., 1997). The present study investigated the potential association between VEGF genetic polymorphisms and prognosis of osteosarcoma in a Chinese population. Our study found that VEGF $+1612 \mathrm{G} / \mathrm{A},-634 \mathrm{G} / \mathrm{C}$, and $+936 \mathrm{~T} / \mathrm{C}$ polymorphisms did not significantly influence the response to chemotherapy, and were not associated with the clinical outcome of patients with osteosarcoma. Our study showed that the VEGF $+1612 \mathrm{G} / \mathrm{A},-634 \mathrm{G} / \mathrm{C}$, and $+936 \mathrm{~T} / \mathrm{C}$ polymorphisms cannot be used as predictive markers for the response to chemotherapy and clinical outcome of patients with osteosarcoma.

Angiogenesis is an important factor in the development and metastasis of tumors, of which VEGF plays a key role and may enhance endothelial cell proliferation and regulate the extracellular matrix in blood vessels (Roy et al., 2006; Kushner and Bautch, 2013). An increasing number of studies have shown that VEGF expression is associated with an increased risk of solid tumors, and increased VEGF expression and microvessel density in tumor tissues are correlated with advanced stage disease and worse prognosis of these solid tumors (Ferrara, 2002; Iordache et al., 2010; Simonetti et al., 2013). Three common SNPs (VEGF +1612G/A, $-634 \mathrm{G} / \mathrm{C}$, and $+936 \mathrm{~T} / \mathrm{C}$ ) in the VEGF gene, located in the 5'- and 3'-untranslated regions of VEGF have been commonly reported to influence protein translation efficiency, circulating plasma concentrations, and tumor tissue expression of VEGF (Watson et al., 2000; Renner et al., 2000; Koukourakis et al., 2004). Several previous studies investigated the role of VEGF polymorphisms and clinical outcome of multiple types of solid tumors, including breast cancer, colorectal cancer, gastric cancer, bladder cancers, and prostate cancer (Jain et al., 2009). However, we found no significant association between VEGF gene polymorphisms and the clinical outcome of osteosarcoma, which disagrees with the results of a previous study (Jain et al., 2009). The inconsistent role of these results may be caused by other functional SNPs in the VEGF gene or other SNPs of the angiogenesis pathway. Further studies are needed to 
elucidate the potential role of VEGF polymorphisms in tumor biology.

This study has several limitations. First, cases were selected from 1 hospital, which may not be representative of the general population. There was still a certain risk of selection bias, as the patients were not a random sample of the osteosarcoma population and may not well-represent the actual situation of patients with osteosarcoma. Second, because of the rarity of osteosarcoma, we examined a small number of cases. The relative small number of cases may have limited the statistical power for identifying difference between groups. Third, other SNPs of the angiogenesis pathway may affect the clinical outcome of osteosarcoma besides the $V E G F$ gene. Therefore, further large sample and well-designed studies are needed to investigate the association between $V E G F$ gene polymorphisms and clinical outcome of osteosarcoma.

In summary, we found that the VEGF $+1612 \mathrm{G} / \mathrm{A},-634 \mathrm{G} / \mathrm{C}$, and $+936 \mathrm{~T} / \mathrm{C}$ polymorphisms did not affect the response to chemotherapy and clinical outcome of osteosarcoma patients. Further studies in Chinese osteosarcoma patients including larger sample sizes are needed.

\section{REFERENCES}

Collins M, Wilhelm M, Conyers R, Herschtal A, et al. (2013). Benefits and adverse events in younger versus older patients receiving neoadjuvant chemotherapy for osteosarcoma: findings from a meta-analysis. J. Clin. Oncol. 31: 2303-2312.

Duong LA and Richardson LC (2013). Descriptive epidemiology of malignant primary osteosarcoma using populationbased registries, United States, 1999-2008. J. Registry Manag. 40: 59-64.

Ferrara N (2002). VEGF and the quest for tumour angiogenesis factors. Nat. Rev. Cancer. 2: 795-803.

Fu Y, Lai Y, Wang Q, Liu X, et al. (2013). Overexpression of clusterin promotes angiogenesis via the vascular endothelial growth factor in primary ovarian cancer. Mol. Med. Rep. 7: 1726-1732.

Jain L, Vargo CA, Danesi R, Sissung TM, et al. (2009). The role of vascular endothelial growth factor SNPs as predictive and prognostic markers for major solid tumors. Mol. Cancer Ther. 8: 2496-2508.

Jaiswal PK, Tripathi N, Shukla A and Mittal RD (2013). Association of single nucleotide polymorphisms in vascular endothelial growth factor gene with bladder cancer risk. Med. Oncol. 30:509.

James R, Ramesh G, Krishnamoorthy L, Bhagat R, et al. (2014). Prevalence of +405G $>C$, $-1154 \mathrm{G}>\mathrm{A}$ vascular endothelial growth factor polymorphism in breast cancer. Indian J. Clin. Biochem. 29: 21-28.

Kapahi R, Manjari M, Sudan M, Uppal MS, et al. (2014). Association of $+405 \mathrm{C}>\mathrm{G}$ and $+936 \mathrm{C}>\mathrm{T}$ polymorphisms of the vascular endothelial growth factor gene with sporadic breast cancer in North Indians. Asian Pac. J. Cancer Prev. 15: 257-263.

Kim JW, Koh Y, Kim DW, Ahn YO, et al. (2013). Clinical implications of VEGF, TGF- $\beta 1$, and IL-1 $\beta$ in patients with advanced non-small cell lung cancer. Cancer Res. Treat. 45: 325-333.

Koukourakis MI, Papazoglou D, Giatromanolaki A, Bougioukas G, et al. (2004). VEGF gene sequence variation defines VEGF gene expression status and angiogenic activity in non-small cell lung cancer. Lung Cancer 46: 293-298.

Kushlinskii NE, Gershtein ES, Nikolaev AA, Delektorskaya VV, et al. (2014). Insulin-like growth gactors (IGF), IGFbinding proteins (IGFBP), and vascular endothelial growth factor (VEGF) in blood serum of patients with colorectal cancer. Bull. Exp. Biol. Med. 156: 684-688.

Kushner EJ and Bautch VL (2013). Building blood vessels in development and disease. Curr. Opin. Hematol. 20: 231-236.

Iordache S, Saftoiu A, Georgescu CV, Ramboiu S, et al. (2010). Vascular endothelial growth factor expression and microvessel density - two useful tools for the assessment of prognosis and survival in gastric cancer patients. $J$. Gastrointest. Liver Dis. 19: 135-139.

Leng WD, He MN, Chen QL, Gong H, et al. (2013). Vascular endothelial growth factor (VEGF) gene polymorphisms and risk of head and neck cancer: a meta-analysis involving 2,444 individuals. Mol. Biol. Rep. 40: 5987-5992.

Longhi A, Fabbri N, Donati D, Capanna R, et al. (2001). Neoadjuvant chemotherapy for patients with synchronous multifocal osteosarcoma: results in eleven cases. J. Chemother. 13: 324-330.

Longhi A, Errani C, De Paolis M, Mercuri M, et al. (2006). Primary bone osteosarcoma in the pediatric age: state of the art. Cancer Treat. Rev. 32: 423-436.

Oh SY, Kwon HC, Kim SH, Lee S, et al. (2013). The relationship of vascular endothelial growth factor gene polymorphisms and clinical outcome in advanced gastric cancer patients treated with FOLFOX: VEGF polymorphism in gastric cancer. BMC Cancer 13: 43. 
Ries LAG, SEER Program [National Cancer Institute (U.S.)] (1999). Cancer incidence and survival among children and adolescents: United States SEER program 1975-1995/ed. by Lynn A. Gloecker Ries et al. National Cancer Institute, SEER Program, Bethesda, MD, USA.

Roy H, Bhardwaj S and Yla-Herttuala S (2006). Biology of vascular endothelial growth factors. FEBS Lett. 580: 28792887.

Salven P, Teerenhovi L and Joensuu H (1997). A high pre-treatment serum vascular endothelial growth factor concentration is associated with poor outcome in non-Hodgkin's lymphoma. Blood 90: 3167-3172.

Savage SA, Woodson K, Walk E, Modi W, et al. (2007). Analysis of genes critical for growth regulation identifies Insulinlike Growth Factor 2 Receptor variations with possible functional significance as risk factors for osteosarcoma. Cancer Epidemiol. Biomarkers Prev. 16: 1667-1674.

Simonetti O, Lucarini G, Rubini C, Goteri G, et al. (2013). Microvessel density and VEGF, HIF-1alpha expression in primary oral melanoma: correlation with prognosis. Oral Dis. 19: 620-627.

Renner W, Kotschan S, Hoffmann C, Obermayer-Pietsch B, et al. (2000). A common 936 C/T mutation in the gene for vascular endothelial growth factor is associated with vascular endothelial growth factor plasma levels. J. Vasc. Res. 37: 443-448.

Vincenti V, Cassano C, Rocchi M and Persico G (1996). Assignment of the vascular endothelial growth factor gene to human chromosome 6p21.3. Circulation 93: 1493-1495.

Wang Z, Wen P, Luo X, Fang X, et al. (2014). Association of the vascular endothelial growth factor (VEGF) gene singlenucleotide polymorphisms with osteosarcoma susceptibility in a Chinese population. Tumour Biol. 35: 3605-3610.

Watson CJ, Webb NJ, Bottomley MJ and Brenchley PE (2000). Identification of polymorphisms within the vascular endothelial growth factor (VEGF) gene: correlation with variation in VEGF protein production. Cytokine 12: 1232-1235. 